\title{
Excretion of clofazimine in human milk in leprosy patients
}

\author{
K. VENKATESAN, A. MATHUR, A. GIRDHAR \& \\ B. K. GIRDHAR \\ Central JALMA Institute for Leprosy, Taj Ganj, Agra, India
}

Accepted for publication 7 May 1997

\begin{abstract}
Summary Clofazimine is an important and effective constituent of multi drug therapy for leprosy. A study has been conducted to determine the distribution of clofazimine in maternal milk so that the safety of breast-feeding during maternal ingestion of the drug can be ascertained. Eight female leprosy patients (LL/BL) on clofazimine, $50 \mathrm{mg}$ daily or $100 \mathrm{mg}$ on alternate days for $1-18$ months, (mean $5.0 \pm 1.81$ months; median 3.25 months) and in the early lactating phase were studied. Blood samples and milk specimens were collected $4-6 \mathrm{hr}$ after the last daily dose. Clofazimine was assayed in the milk and plasma samples by HPTLC. Mean plasma and milk clofazimine levels were $0.9 \pm 0.03 \mu \mathrm{g} / \mathrm{ml}$ and $1.33 \pm 0.09 \mu \mathrm{g} / \mathrm{ml}$ respectively. The ratio of milk to plasma drug concentration ranged from 1.0 to 1.7 with a mean of $1.48 \pm 0.08$. The amount of drug ingested by the infants was $0 \cdot 199 \pm 0 \cdot 013 \mathrm{mg} / \mathrm{kg} /$ day which represented $22 \cdot 1 \pm 1 \cdot 9 \%$ of the maternal dose.
\end{abstract}

\section{Introduction}

Clof azimine, 3-(p-chloroanilino)-10-(p-chlorophenyl)-2, 10-dihydro-2-(isopropylimino) phenazine, is an effective antileprosy drug. It is a part of the multi drug therapy (MDT) for leprosy and is given at a dose of $50 \mathrm{mg}$ daily or $100 \mathrm{mg}$ on every other day. ${ }^{1}$ It is also useful in the management of erythema nodosum leprosum at higher doses, usually $200-300 \mathrm{mg}$ daily. ${ }^{2}$ Slow absorption, relatively much slower distribution and longer retention in selective tissues are peculiar features of clofazimine metabolism. ${ }^{3}$ The plasma concentration of the drug is dose related, although there does not appear to be a linear relationship between doses and plasma concentrations. A steady state is expected to be attained with oral administration of clofazimine $50 \mathrm{mg}$ daily for more than 30 days. $^{4}$

There are isolated reports on pigmentation of the infants born to leprosy patients on clofazimine therapy ${ }^{5,6}$ and the mammary excretion of the drug in experimental animals. ${ }^{7}$ Recently there has been a report on excretion of significant amounts of clofazimine in the breast milk of a woman in Nepal. ${ }^{8}$ Since the safety of drug ingestion via maternal milk by suckling infants is of considerable importance, the present study was carried out to quantitate the mammary excretion of clofazimine in patients and determine milk to plasma concentration ratio as well as the approximate levels of the drug ingested by suckling infants. 


\section{Materials and methods}

Eight female leprosy patients (LL/BL) who were in the early lactation period of upto 4 months formed the subjects of the study. They were aged 19-35 years with the mean age of $28 \pm 2 \cdot 17$ (SE) years. As a part of MDT (comprising of rifampicin $600 \mathrm{mg}$ once a month, dapsone $100 \mathrm{mg}$ daily and clofazimine $50 \mathrm{mg}$ daily or $100 \mathrm{mg}$ on alternate days) all patients had taken clofazimine for 1-18 months with a mean of $5 \cdot 0 \pm 1 \cdot 81$ months. One patient had received the drug $100 \mathrm{mg}$ daily while 2 patients received $100 \mathrm{mg}$ on alternate days and remaining patients were on $50 \mathrm{mg}$ daily. Milk specimens and blood samples were collected 4-6 hr after administering the day's dose with breakfast.

Plasma was separated and both milk and plasma samples were either processed for clofazimine assay immediately or stored at $-20^{\circ} \mathrm{C}$ till assay. Clofazimine was assayed by the method of Lanyi \& Dubois ${ }^{9}$ based on high performance thin layer chromatography (HPTLC) coupled with densitometric scanning. Briefly $1-3 \mathrm{ml}$ of plasma/milk were acidified with $2 \mathrm{ml}$ of acetate buffer $(1 \mathrm{M}, \mathrm{pH} 5 \cdot 0)$ and extracted with $6 \mathrm{ml}$ of toluene for $15 \mathrm{~min}$. After brief centrifugation, the organic layer was removed and evaporated to dryness under a stream of nitrogen at $40^{\circ} \mathrm{C}$. The residue was redissolved in $100 \mu \mathrm{l}$ of methanol and applied on to HPTLC silica gel 60 Plate (Merck) predeveloped with chloroform : methanol $(1: 1 \mathrm{v} / \mathrm{v})$ prior to use. The plates spotted with clofazimine extracts and standards were developed in toluene-acetic acid-water $(50: 50: 4 \mathrm{v} / \mathrm{v})$. In situ quantitation of the TLC spots were performed with a Shimadzu (Japan) TLC Scaner at $550 \mathrm{~nm}$. Two samples containing aliquot of clofazimine extracts were also run on high performance liquid chromatography (HPLC) Shim pack C8 column using a mobile phase of $0.0425 \mathrm{M}$ Phosphoric acid in $81 \%$ methanol $(\mathrm{pH} 2.4)$ at a flow rate of $1.5 \mathrm{ml} / \mathrm{mt}$ and quantitated at $285 \mathrm{~nm} .^{10}$

The ratio of milk to plasma clofazimine concentrations was calculated and the approximate amount of the drug ingestion by suckling infants was calculated assuming that an infant aged 2-3 months and weighing $2 \cdot 5 \mathrm{~kg}$ would consume breast milk at a rate of $150 \mathrm{ml} / \mathrm{kg}$ bodyweight/day on average. ${ }^{11}$ The percentage of last maternal dose, in $\mathrm{mg} / \mathrm{kg}$, ingested by the infants was also determined.

\section{Results}

The plasma clofazimine levels ranged between 0.8 and $1.0 \mu \mathrm{g} / \mathrm{ml}$ with mean value of $0.9 \pm 0.03 \mu \mathrm{g} / \mathrm{ml}$ while the milk drug levels ranged from 0.8 to $1.7 \mu \mathrm{g} / \mathrm{ml}(1.33 \pm 0.09)$. The ratio of milk drug concentration to plasma drug concentration (M/P) ranged from 1.0 to $1 \cdot 7$, (mean $1.48 \pm 0.08$ ) $4-6 \mathrm{hr}$ after the last daily dose. The quantities of clofazimine ingested daily by suckling infants ranged from $0.120 \mathrm{mg} / \mathrm{kg} /$ day to $0.255 \mathrm{mg} / \mathrm{kg} /$ day $(0.199 \pm 0.013)$ which, when expressed as a percentage of the last maternal dose in $\mathrm{mg} / \mathrm{kg}$, represented $13 \cdot 5$ to $30 \%(22 \cdot 11 \pm 1 \cdot 90)$ (Table 1$)$.

\section{Discussion}

Clofazimine is a highly lipophilic drug. The mechanisms of its absorption, distribution and retention are far from clear. Leprosy patients receiving the drug at $100 \mathrm{mg}$ thrice weekly or $100 \mathrm{mg}$ daily for varying periods have shown plasma drug levels of 0.5 or $0.7 \mu \mathrm{g} / \mathrm{ml}$ 
respectively. ${ }^{12}$ A single oral dose of $200 \mathrm{mg}$ results in a mean plasma level of $0 \cdot 4 \mu \mathrm{g} / \mathrm{g} .{ }^{4}$ An average plasma concentration of $1 \cdot 15 \mu \mathrm{g} / \mathrm{ml}$ has been reported in leprosy patients receiving a daily dose of $300 \mathrm{mg} .{ }^{13}$ The patients included in the present study were on clofazimine $50 \mathrm{mg}$ daily or $100 \mathrm{mg}$ alternate days for 1-18 months. Since a daily continuous daily administration of $50 \mathrm{mg}$ of the drug for 30 days is likely to result in a 'steady-state level', ${ }^{4}$ plasma drug concentrations of $0.8-1.0 \mu \mathrm{g} / \mathrm{ml}$ presented by the patients in the present study might represent the steady-state levels and at this stage one could look for an equilibrium between plasma and milk compartments.

The distribution of clofazimine is relatively slower than its absorption. Clofazimine and related phenazines have been reported to show very selective tissue distribution. A significant proportion of the drug is found in adipose tissues and in cells of the reticuloendothelial system, where they can be seen concentrated in phagosome type inclusions and ultimately as crystals of pure drug. ${ }^{14}$ Presumably clofazimine after absorption circulates bound to plasma proteins and is engulfed in this form by the cells of the reticuloendothelial system, where it remains after digestion of the proteins. ${ }^{7}$ Clofazimine and its metabolites are excreted in urine in very small amounts constituting $1.6 \%$ of the daily dose (assuming $70 \%$ drug absorption). ${ }^{15,16}$ The low excretion rate is probably due to retention of the drug in the body for a long time. Based on an observation that infants born to mothers who had received the drug during pregnancy were deeply pigmented at birth, it has been reported that clofazimine crosses the placenta. ${ }^{5}$ However, no teratogenic effect has been reported with clofazimine. ${ }^{6}$

Decisions about the safety of breast-feeding during maternal ingestion of the drug require knowledge of the amount of the drug which might be present in the milk. There are only scanty reports on the excretion of dapsone, rifampicin and clofazimine in breast milk. Lactating mothers on 100-150 mg dapsone daily were found to have serum levels of $1.62 \mu \mathrm{l} / \mathrm{ml}$ with milk levels of $1.09 \mu \mathrm{g} / \mathrm{ml}$ resulting in milk : plasma (M/P) ratio of 0.7 . The breast-fed infants had serum dapsone levels of $0 \cdot 493 \mu \mathrm{g} / \mathrm{ml} .{ }^{17}$ Experimental studies in female mice, rats, guinea-pigs and rabbits have shown transmission of significant amounts of clofazimine to the offspring via mother's milk. In a TLC-NMR Spectroscopic analysis of milk from a Nepali woman, a considerable amount of clofazimine was found to be released from the body with the mother's milk. ${ }^{8}$ Our study has included a larger number of lactating patients on varying lengths of chemotherapy and clofazimine has been quantitated in both plasma and single milk sample from all 8 patients.

Since the total quantity of milk during a period of $24 \mathrm{hr}$ or part of it could not be collected the studies had to be limited to single samples. The drug ingestion by the suckling infants was calculated assuming that the volume of milk consumed by the infant aged 2-3 months is about $150 \mathrm{ml} / \mathrm{kg} /$ day. ${ }^{11}$ The values for the suckling infants of 8 patients ranged from $0 \cdot 120 \mathrm{mg} / \mathrm{kg} /$ day to $0 \cdot 255 \mathrm{mg} / \mathrm{kg} /$ day with a mean of $0 \cdot 199 \pm 0 \cdot 013 \mathrm{mg} / \mathrm{kg} / \mathrm{day}$. The highest level of drug ingestion by the infant of subject No. 1 would then represent $30 \%$ of last daily dose $(\mathrm{mg} / \mathrm{kg}$ ) by the subject who had taken $26.6 \mathrm{~g}$ of the drug cumulatively.

The accumulated total dose of clofazimine does not seem to proportionately influence the excretion of the drug in milk as shown by the figures of subject No. 5 versus subject No. 1 (Table 1). Even when the total intake by subject No. 5 was only $1.5 \mathrm{~g}$, the amount of the drug excreted into milk was almost the same as in the case of subject No. 1 who had taken about 20 times more of the drug cumulatively. This indicates that the clofazimine mobilized from the fixed dose within the cells of the tissues into extra vascular space and subsequently into milk, may not be important in view of slow elimination phase for the drug. The extent of drug ingestion has, therefore, been expressed as a percentage of the last maternal daily dose in 
Table 1. Milk and plasma levels of clofazimine in lactating female leprosy patients on administration of the drug orally for 1-18 months

\begin{tabular}{|c|c|c|c|c|c|c|c|}
\hline \multirow[b]{2}{*}{ Subject } & \multirow{2}{*}{$\begin{array}{l}\text { Length of } \\
\text { treatment } \\
\text { (months) }\end{array}$} & \multirow{2}{*}{$\begin{array}{c}\text { Total } \\
\text { intake } \\
(\mathrm{g})\end{array}$} & \multicolumn{2}{|c|}{$\begin{array}{l}\text { Clofazimine levels } 4-6 \mathrm{hr} \\
\text { after last oral dose }\end{array}$} & \multirow[b]{2}{*}{$\begin{array}{l}\mathrm{M} / \mathrm{P} \\
\text { ratio }\end{array}$} & \multirow{2}{*}{$\begin{array}{c}\text { Drug ingested } \\
\text { by infants } \\
\text { (mg/kg/day) }\end{array}$} & \multirow[b]{2}{*}{$\begin{array}{c}\% \text { maternal } \\
\text { doses } \ddagger\end{array}$} \\
\hline & & & $\begin{array}{l}\text { Plasma } \\
(\mu \mathrm{g} / \mathrm{ml})\end{array}$ & $\begin{array}{l}\text { Milk } \\
(\mu \mathrm{g} / \mathrm{ml})\end{array}$ & & & \\
\hline 1 & 18 & $26 \cdot 6$ & $1 \cdot 0$ & $1 \cdot 7$ & 1.7 & $0 \cdot 255$ & $30 \cdot 0$ \\
\hline 2 & 6 & $17 \cdot 6$ & 0.9 & 1.5 & 1.7 & $0 \cdot 225$ & $13 \cdot 5$ \\
\hline 3 & 4 & $6 \cdot 5$ & $0 \cdot 8$ & $1 \cdot 3$ & 1.6 & $0 \cdot 195$ & $23 \cdot 4$ \\
\hline 4 & 4 & $6 \cdot 0$ & 1.0 & 1.4 & 1.4 & $0 \cdot 210$ & $25 \cdot 2$ \\
\hline 5 & 1 & 1.5 & $0 \cdot 8$ & $0 \cdot 8$ & 1.0 & $0 \cdot 120$ & $14 \cdot 4$ \\
\hline $6 \dagger$ & 2 & 3.0 & 1.0 & 1.4 & 1.4 & $0 \cdot 210$ & $25 \cdot 2$ \\
\hline 7 & 2 & $2 \cdot 7$ & $0 \cdot 8$ & $1 \cdot 1$ & 1.4 & $0 \cdot 165$ & $20 \cdot 0$ \\
\hline $8 \dagger$ & 3 & $4 \cdot 3$ & 0.9 & $1 \cdot 4$ & $1 \cdot 6$ & $0 \cdot 210$ & $25 \cdot 2$ \\
\hline \multicolumn{2}{|c|}{$\begin{array}{r}\text { Mean } \pm \operatorname{SE} 5 \cdot 0 \pm 1 \cdot 81 \\
\text { Median 3.25 }\end{array}$} & $8.53 \pm 2.93$ & $0.9 \pm 0.03$ & $1.33 \pm 0.09$ & $1.48 \pm 0.08$ & $0 \cdot 199 \pm 0.013$ & $22 \cdot 11 \pm 1 \cdot 90$ \\
\hline
\end{tabular}

* On clofazimine $100 \mathrm{mg}$ daily.

$\dagger$ On clof azimine $100 \mathrm{mg}$ on alternate days.

$\ddagger$ Maternal doses as $\mathrm{mg} / \mathrm{kg}$.

$\mathrm{mg} / \mathrm{kg}$. The experimental data in animals have shown that the rate of drug passage between the mammary gland and plasma is more rapid for drugs that are highly lipid soluble and unionized. ${ }^{18}$ The high lipid solubility and moderately low molecular weight of clofazimine might favour rapid passage between mammary gland and plasma of lactating mothers.

It may be concluded that in spite of clofazimine in breast milk in significant quantities and the infant ingestion of about $0 \cdot 225 \mathrm{mg} / \mathrm{kg} / \mathrm{day}$ discontinuation of clofazimine use need not be recommended to lactating mothers till further studies with toxicity data are available.

\section{Acknowledgment}

The authors wish to thank the Nursing Staff of the Institute for help in obtaining breast milk and blood samples from the patients. Secretarial assistance of Sh. J. D. Kushwah is gratefully acknowledged. Micronized clofazimine powder was a gift from Ciba-Geigy, Basel, Switzerland.

\section{References}

${ }^{1}$ WHO Study Group. Chemotherapy for Leprosy Control Programmes. Technical Report Series No. 675, WHO: Geneva, 1982.

2 Aquas JT. Treatment of leprosy with lamprene (B 663 Geigy). Int. J. Lepr. 1971: 39: 493-503.

3 Venkatesan K. Clinical Pharmacokinetic considerations in the treatment of patients with leprosy. Clin. Pharmacokinet. 1989; 16: 365-386.

${ }^{4}$ Lanyi Z, Dieterie W, Dubois JP, Theobald W, Vischer W. Pharmacokinetics of clof azimine in healthy volunteers. Int. J. Lepr. 1987; 55: 9-15.

5 Waters MMF. G 30320 or B 663, Lamprene (Geigy); a working party held in London in September 1968. Lepr. Rev. 1969; 40: 21-47. 
${ }^{6}$ Schulz EJ. Forty four months' experience in the treatment of leprosy with Clofazimine (Lamprene-Geigy). Lepr. Rev 1971; 42: 178-187.

7 Vischer WA. The experimental properties of G 30320 (B663) - A new anti-leprotic agent. Lepr. Rev. 1969; 40: 107-110.

${ }^{8}$ Freerksen E, Seydel JK. Critical comments on the treatment of leprosy and other mycobacterial infections with clofazimine. Arzneimittel forschung (Drug Res.) 1992; 42: 1243-1245.

9 Lanyi Z, Dubois JP. Determination of clof azimine in human plasma by thin layer Chromatography. J. Chromatogr. 1982; 232: 219-223.

10 Peters JH, Hamme KJ, Gordon GR. Determination of clofazimine in plasma by high performance liquid chromatography. J. Chromatogr. 1982; 229: 503-508.

11 Atkinson HC, Begg EJ. Prediction of Drug distribution into human milk from physicochemical characteristics. Clin. Pharmacokinet. 1990; 18: 151-167.

12 Banerjee DK, Ellard GA, Gammon PT, Waters MFR. Some observations on the pharmacology of clofazimine (B663). Am. J. Trop. Med. Hyg. 1974; 23: 1110-1115.

13 Balakrishnan S, Desikan KV, Ramu G. Quantitative estimation of clofazimine in tissues. Lepr. India 1976; 40: (Suppl. 4): 732-738.

14 Conalty ML, Jackson RD. Uptake by reticuloendothelial cells of riminophenazine B663. Br. J. Exptl. Pathol. 1962; 43: 650-654.

15 Levy L. Pharmacological studies of clofazimine. Am. J., Trop. Med Hyg. 1974; 23: 1097-1109.

${ }^{16}$ Feng PCC, Fenselau CC, Jacobson RR. Metabolism of clofazimine in leprosy patients. Drug Met. Disposition 1981; 9: 521-524.

17 Sanders SW, Zone JJ, Poltz RI, Tolman KG, Rollins DE. Haemolytic anaemia induced by dapsone transmitted through breast milk. Annals Int. Med. 1982; 96: 465-466.

18 Rasmussen F. Studies in the mammary excretion and absorption of drugs, Mortensen, Copenhagen, 1966. 